\title{
PREDIKSI HASIL PRODUKSI IKAN TUNA MENGGUNAKAN ALGORITMA NEURAL NETWORK BERBASIS FORWARD SELECTION
}

\author{
Salman Suleman ${ }^{1)}$, Roys Pakaya ${ }^{2)}$ \\ 1. Dosen Program Studi D3 Teknik Informatika, Politeknik Gorontalo \\ 2. Dosen Program Studi D3 Teknik Informatika, Politeknik Gorontalo \\ Jl. Muchlis Rahim Desa Panggulo, Kecamatan Botupingge \\ Kabupaten Bone Bolango, Provinsi Gorontalo \\ E-mail : salmansulean@poligon.ac.id ${ }^{1)}$,royspakaya @ poligon.ac.id ${ }^{2)}$
}

\begin{abstract}
ABSTRAK
Potensi perikanan dan kelautan merupakan modal dasar pembangunan Provinsi Gorontalo. Berdasarkan persentase rata-rata hasil produksi ikan tuna yang meningkat setiap tahunnya maka perlu dilakukan prediksi hasil produksi ikan tuna dalam rangka peningkatan sektor produksi perikanan kelautan. Metode prediksi times series mimiliki tingkat error data yang rendah dan baik yaitu Neural Network. Metode pelatihan yang dapat digunakan dalam memperbaiki bobot jaringan syaraf tiruan adalah backpropagation. Akan tetapi terdapat beberapa kelemahan diantaranya masalah waktu pelatihan yang lama dalam mencapai konvergen, dan masalah pada overfitting.

Untuk itu dalam mengatasi masalah pada metode Neural Nerwork pada penelitian ini ditambahkan metode seleksi fitur yang akan digunakan yaitu forward selection dengan harapan mampu menghasilkan tingkat akurasi yang lebih baik. Dengan penggunaan fitur selection dalam jaringan syaraf tiruan mampu mempercepat waktu kalkulasi dan mendapatkan hasil prediksi yang akurat, sehingga dapat digunakan dalam memprediksi hasil produksi ikan tuna.

Dengan membandingkan hasil Root Mean Square Error (RMSE) menggunakan Neural Network yaitu 0,096, sedangkan dengan menggunakan metode Neural Network berbasis Forward Selection didapatkan hasil Root Mean Square Error (RMSE) yaitu 0,080. Hal ini membuktikan bahwa dengan menerapkan pola yang didapatkan dari metode Neural Network Berbasis Forward Selection dalam melakukan prediksi mampu mengurangi nilai Root Mean Square Error (RMSE) dengan hasil selisih yaitu sebesar 0,016.
\end{abstract}

Kata Kunci : Prediski, tuna, neural network, forward selection

\begin{abstract}
Fishery and marine potency is the basic capital of Gorontalo Province development. Based on the average percentage of tuna fish production that increases every year, it is necessary to predict the yield of tuna fish in order to increase marine fisheries production sector. The time series prediction method has a low and good error rate of Neural Network. The training method that can be used in improving artificial neural network weights is backpropagation. However, there are some disadvantages such as the problem of long training time in reaching convergent, and the problem of overfitting.

For that in overcoming the problem on the method of Neural Nerwork in this study added the method of selection of features that will be used that is forward selection in the hope of able to produce a better level of accuracy. Using the selection feature in artificial neural networks can speed up calculation time and get accurate prediction results, so it can be used in predicting the production of tuna.

By comparing the result of Root Mean Square Error (RMSE) using Neural Network is 0,096, whereas by using Neural Network based Forward Selection method Root Mean Square Error (RMSE) is 0,080. This proves that by applying the pattern obtained from Neural Network Based Forward Selection method in doing the prediction able to reduce Root Mean Square Error (RMSE) value with difference result that is equal to 0,016.
\end{abstract}

Kata kunci : Prediski, tuna, neural network, selection forward

doi:10.30869, issn:2252-4002/2546-558X

PREDIKSI HASIL PRODUKSI IKAN TUNA MENGGUNAKAN ALGORITMA NEURAL NETWORK

BERBASIS FORWARD SELECTION 


\section{PENDAHULUAN}

Potensi hasil produksi ikan tuna Provinsi Gorontalo tidak bisa dipisahkan dari potensi perikanan tangkap yang bebasis pada WPP (Wilayah Pengelolaan dan Pemanfaatan) dan di akui secara Nasional maupun Internasional. Potensi hasil produksi ikan tuna Provinsi Gorontalo masuk dalam 2 (dua) WPP yaitu : WPP 715 (perairan Teluk Tomini sampai Perairan Laut Seram) potensi perikanan tuna : 595.630 Ton Per tahun, WPP 716 (Laut Sulawesi sampai samudra pasifik bagian utara pulau Halmahera dan irian jaya) Potensi Perikanan tuna : 630.470 Ton Per tahun. Potensi ini sudah termasuk potensi perikanan di wilayah ZEE pada wilayah tersebut. Tapi, jika kita pisahkan berdasarkan potensi di wilayah ZEE laut Sulawesi sampai Samudra Pasifik (bagian Utara Irian Jaya) sebesar 487.600 ton per tahun atau 21,2 \% dari total Potensi perikanan di wilayah ZEE Indonesia yaitu 2,3 juta Ton. Hasil produksi ikan tuna Gorontalo tahun 2007-2012 mengalami kenaikan rata-rata sebesar 9,8\% per tahun, dari 49.962 ton pada tahun 2007 menjadi 76.369 ton pada tahun 2011 [2].

Sektor kelautan dan perikanan merupakan sektor yang mendukung peningkatan ekonomi kerakyatan dalam rangka percepatan pembangunan infrastruktur pedesaan dan dapat memberikan manfaat bagi potensi sumberdaya perikanan dan kelautan melalui peningkatan produksi ikan tuna serta dalam pengolahan ikan dengan menciptakan usaha perikanan dan kelautan yang sehat, kompetitif dengan memberikan dorongan kemudahan dan kesempatan bagi masyarakat kurang mampu untuk melakukan usaha perikanan dan kelautan. Dengan memilihara kualitas lingkungan hidup perairan untuk menjamin potensi sumberdaya perikanan dan kelautan dapat memberikan kesejahteraan terhadap masyarakat Gorontalo secara berkelanjutan.

Berdasarkan persentase rata-rata hasil produksi ikan tuna yang meningkat setiap tahunnya maka perlu dilakukan prediksi hasil produksi ikan tuna dalam rangka peningkatan sektor produksi perikanan kelautan dan menjadikan parameter terbaik dalam memprediksi hasil produksi ikan tuna.

Pemilihan metode dalam peramalan rentet waktu merupakan salah satu faktor yang sangat penting untuk mendapatkan akurasi yang baik. Metode peramalan rentet waktu mimiliki tingkat error data yang yang rendah dan baik yaitu
Neural Network yang digunakan pada beberapa penelitian dalam melakukan peramalan data time series, akan tetapi dalam penerapan metode ini masih terdapat beberapa kelemahan diantaranya masalah waktu pelatihan yang lama dalam mencapai konvergen, dan masalah pada overfitting dalam motode ini. Penentuan parameter learning rate dan momentum yang tepat yang menjadi kendala tersendiri dalam proses pelatihan [3].

Untuk itu dalam mengatasi masalah pada metode Neural Nerwork pada penelitian ini ditambahkan metode seleksi fitur yang akan digunakan yaitu forward selection dengan harapan mampu menghasilkan tingkat akurasi yang lebihbaik.

Forward selection adalah salah satu metode seleksi fitur yang dapat digunakan untuk mengurangi atribut yang kurang relevan padadataset.Forward selection dapat berarti menambahkan variabel bebas atau independentyang memiliki correlation yang paling erat dengan variabel tidak bebas atau dependent(variabel yang paling potensial untuk memiliki hubungan linier dengan Y). Kemudian secara bertahap memasukkan variabel bebas yang potensial berikutnya dan akan terhenti jika tidak ada lagi variabel bebas yang potensial.

Dalam penelitian ini dilakukan dengan menggunakan metode Neural Network yang kemudian akan ditambahkan dengan fitur seleksi Forward selection alam memprediksi hasil produksi ikan tuna. Dengan penggunaan metode ini diharapkan mampu untuk mengurangi nilai error yang dihasilkan oleh metode Neural Network sehingga dapat memperoleh nilai akurasi yang akurat dan tingkat konvergensi yang lebih stabil.

\section{TINJAUAN PUSTAKA}

\subsection{Penelitian Terkait}

Berdasarkan penelitian yang dilakukan oleh Chih-Yao Lo dkk [3] yang menggunakan metode prediksi peramalan pelanggan produksi ikan dengan algoritma Backpropagation Neural Network dengan menggunakan data produksi ikan Ruixiang grosir di tahun 2009, dan data yang digunakan dalam training dan testing berupa jumlah pesanan ikan perkuartal pada tahun 2009. Dengan hasil pengujian nilai Mean Square Error (MSE) yaitu $10^{-15} \sim 10^{16}$ untuk data training sedangkan rata-rata pada data testing yaitu $64,3 \%$ dan learnig time sebesar 4089 yang merupakan hasil terbaik dari pengujian terhadap jumlah permintaan pelanggan.

Berdasarkan penelitian yang dilakukan diatas, dalam penelitian ini dilakukan dengan menggunakan metode Neural Network berbasis Forward Selection dalam memprediksi hasil produksi ikan tuna diharapkan mampu untuk mengurangi nilai error yang dihasilkan oleh metode Neural Network sehingga dapat memperoleh nilai akurasi yang akurat dan tingkat konvergensi yang lebih stabil. 


\subsection{Tuna}

Tuna adalah ikan laut pelagik yang termasuk bangsa Thunnini, terdiri dari beberapa spesies dari famili skombride, terutama genus Thunnus. Ikan ini adalah perenang andal (pernah diukur mencapai $77 \mathrm{~km} / \mathrm{jam}$ ). Tidak seperti kebanyakan ikan yang memiliki daging berwarna putih, daging tuna berwarna merah muda sampai merah tua. Hal ini karena otot tuna lebih banyak mengandung myoglobin daripada ikan lainnya. Beberapa spesies tuna yang lebih besar, seperti tuna sirip biru Atlantik (Thunnus thynnus), dapat menaikkan suhu darahnya di atas suhu air dengan aktivitas ototnya. Hal ini menyebabkan mereka dapat hidup di air yang lebih dingin dan dapat bertahan dalam kondisi yang beragam. Kebanyakan bertubuh besar, tuna adalah ikan yang memiliki nilai komersial tinggi.

Tuna memiliki bentuk tubuh yang sedikit banyak mirip dengan torpedo, disebut fusiform, sedikit memipih di sisi-sisinya dan dengan moncong meruncing. Sirip punggung (dorsal) dua berkas, sirip punggung pertama berukuran relatif kecil dan terpisah dari sirip punggung kedua. Di belakang sirip punggung dan sirip dubur (anal) terdapat sederetan sirip-sirip kecil tambahan yang disebut finlet. Sirip ekor bercabang dalam (bercagak) dengan jari-jari penyokong menutup seluruh ujung hipural. Di kedua sisi batang ekor masing-masing terdapat dua lunas samping berukuran kecil; yang pada beberapa spesiesnya mengapit satu lunas samping yang lebih besar. Tubuh kebanyakan dengan wilayah barut badan (corselet), yakni bagian di belakang kepala dan di sekitar sirip dada yang ditutupi oleh sisik-sisik yang tebal dan agak besar. Bagian tubuh sisanya bersisik kecil atau tanpa sisik. Tulang-tulang belakang (vertebrae) antara 31-66 buah.

Aspek yang luar biasa dari fisiologi tuna adalah kemampuannya untuk menjaga suhu tubuh lebih tinggi daripada suhu lingkungan. Sebagai contoh, tuna sirip biru dapat mempertahankan suhu tubuh $75-95^{\circ} \mathrm{F}$ $\left(24-35^{\circ} \mathrm{C}\right)$, dalam air dingin bersuhu $43{ }^{\circ} \mathrm{F}$ $\left(6{ }^{\circ} \mathrm{C}\right)$. Tuna mampu melakukan hal tersebut dengan cara menghasilkan panas melalui proses metabolisme. Rete mirabile, jalinan pembuluh vena dan arteri yang berada di pinggiran tubuh, memindahkan panas dari darah vena ke darah arteri. Hal ini akan mengurangi pendinginan permukaan tubuh dan menjaga otot tetap hangat. Ini menyebabkan tuna mampu berenang lebih cepat dengan energi yang lebih sedikit.[4]

\section{METODE PENELITIAN}

Adapun desain penelitian yang dilakukan pada penelitian ini adalah sebagai berikut :

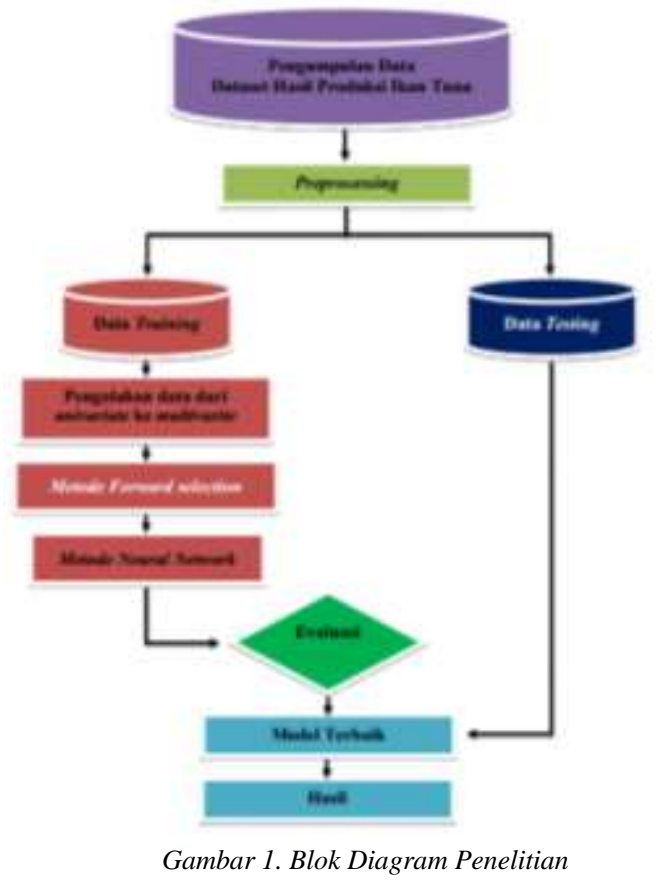

\subsection{Pengumpulan Data}

Pada penelitian ini data yang digunakan adalah data yang diperoleh dari Kantor Dinas Perikanan Kabaputan Gorontalo, Kantor Dinas Perikanan dan Kelautan Boalemo, Kantor Dinas Perikanan danKelautan Bone Bolango, berupa data time series univariat, data tersebut adalah data hasil produksi ikan tuna yangdimulai dari tahun 2014 sampai dengan 2017 secara per minggu dalam satuan Kilogram ( $\mathrm{Kg})$.

\subsection{Preprocessing Data}

Tahap Preprocessing data yang dilakukan dalam penelitian ini yaitu dengan melakukan normalisasi data dengan tujuan untuk mengelompokkan data ke dalam jangkauan tertentu agar dapat memudahkan proses pengolahan data. Normalisasi yang digunakan dalam penelitian ini yaitu jangkauan (0.1).

\subsection{Pengujian Algoritma}

Pada tahap ini dilakukan pengujian terhadap algoritma yang diusulkan yaitu metode Neural Networkdengan menentukan jumlah presentase data training yaitu $90 \%$ dan testing sebesar 10\%. Dari hasil data yang telah dirubah ke multivariat diuji dengan metode Neural Network. Untuk mendapatkan arsitektur yang tepat dilakukan pengaturan parameter-parameter antar lain :

a. Penentuan parameter Neural Network 
1. Input layeradalah jumlah data yang dimasukkan untuk sebagai pembelajaran. Dalam penelitian ini penentuan input layer sesuai dengan jumlah variable dari jumlah data yaitu 12 variabel.

2. Hidden layer dalam penentuan parameter hidden layer bisa memiliki dari lebih dari satu hidden layer akan tetapi jika jumlah neuron yang ditentukan terlalu sedikit akan mengakibatkan underfitting, dan jika neuron yang ditentukan terlalu banyak akan mengakibatkan overfitting. Pada penelitian ini penentuan Hidden layer dilakukan uji coba dengan nilai neuron size 2 sampai dengan 15.

3. Training cycleatau iterasi (epoch) adalah banyak perulangan yang terdapat pada tahapan algoritma. Dalam penentuan Training cycle untuk uji coba dalam penelitian ini dengan memasukkan nilai range 100, 200, 300 sampai dengan 1500.

4. Learning rate adalah parameter yang digunakan algoritma Neural Network dalam bobot dari neuron. Penentuan nilai learning rate mulai dari 0,1 sampai dengan 1. Semakin besar nilai yang akan diberikan akan menyebabkan pembelajaran lebih cepat, akan tetapi jika nilai yang diberikan kecil akan menyebabkan proses pembelajaran lebih lambat. Dalam penelitian penelitian ini dilakukan uji coba dengan memasukkan nilai pelatihan 0.1 sampai dengan 1.

5. Momentum digunakan untuk meningkatkan convergence dan mempercepat proses waktu pembelajaran yang memiliki batasan nilai yaitu 0 sampai dengan 0,9 . Untuk mendapatkan nilai Momentum dilakukan uji coba dengan memasukkan nilai pelatihan 0.1 sampai dengan 0.9

6. Output layeradalah jumlah keluaran dari hasil proses algoritma Neural Network. Dalam penelitian ini yakni 1 Output layer.

7. Number of Validation yang digunakan adalah 10 .

Setelah dilakukan penentuan parameter akan dilakukan pengujian proses training dengan menerapkan arsitektur terbaik dan nilai RMSE yang terkecil yang diperoleh Neural Network untuk mencari posisi nilai terbaiknya dengan meminimalkan nilai error dihasilkan yang nantinya akan menjadi parameter terbaik dalam melakukan prediksi yang akan datang.

\section{HASIL DAN PEMBAHASAN}

Tahapan proses awal yang dilakukan sebelum melakukan pengujian menggunakan metode Forward Selection dan Neural Network dilakukan tahap normalisasi data. Dalalm proses normalisasi dilakukan terhadap semua record data yang nantinya akan diolah.

Adapun proses normalisasi yang dilakukan ujicoba pada satu record data seperti yang terlihat dalam contoh dibawah ini:

Data hasiabel produksi ikan tuna

$=2283$

Nilai tertinggi dari variabel hasil produksi ikan tuna $=60541$

Nilai terkecil dari variabel hasil produksi ikan tuna $=233$

Penyelesaian :

$$
\begin{aligned}
& X^{\prime}=\frac{0,8(2283-233)}{(60541-233)}+0,1 \\
& X^{\prime}=\frac{0,8(2050)}{(60308)}+0,1 \\
& X^{\prime}=\frac{1640}{60308}+0,1 \\
& X^{\prime}=0,0272+0,1 \\
& X^{\prime}=0,1272
\end{aligned}
$$

Tabel 1. Hasil Normalisasi Data

\begin{tabular}{|c|c|}
\hline Minggu Ke & Hasil Produksi Ikan Tuna $(\mathrm{Kg})$ \\
\hline Minggu 1 & 0.1272 \\
\hline Minggu 2 & 0.1346 \\
\hline Minggu 3 & 0.1352 \\
\hline Minggu 4 & 0.1383 \\
\hline Minggu 5 & 0.1578 \\
\hline Minggu 6 & 0.1198 \\
\hline Minggu 7 & 0.1404 \\
\hline Minggu 8 & 0.1311 \\
\hline Minggu 9 & 0.1714 \\
\hline Minggu 10 & 0.1553 \\
\hline Minggu 11 & 0.1535 \\
\hline Minggu 12 & 0.2552 \\
\hline Minggu 13 & 0.1829 \\
\hline Minggu 14 & 0.2524 \\
\hline Minggu 15 & 0.1826 \\
\hline
\end{tabular}

Berdasarkan data diatas yang telah dilakukan normalisasi susunan datanya dari ascending seperti pada tabel 2 kemudian diubah kedalam ke descending seperti 
yang ditunjukkan pada tabel 2. Selanjutnya dari data time series univariat kedalam bentuk multivariat.

Tabel 2. Hasil Normalisasi Data

\begin{tabular}{|c|c|}
\hline Minggu Ke & $\begin{array}{c}\text { Hasil Produksi Ikan } \\
\text { Tuna }(\mathrm{Kg})\end{array}$ \\
\hline Minggu 192 & 0.1024 \\
\hline Minggu 191 & 0.1038 \\
\hline Minggu 190 & 0.1024 \\
\hline Minggu 189 & 0.1038 \\
\hline Minggu 188 & 0.1274 \\
\hline Minggu 187 & 0.1351 \\
\hline Minggu 186 & 0.1256 \\
\hline Minggu 185 & 0.1368 \\
\hline Minggu 184 & 0.1578 \\
\hline Minggu 183 & 0.1564 \\
\hline Minggu 182 & 0.2126 \\
\hline Minggu 181 & 0.1720 \\
\hline Minggu 180 & 0.1825 \\
\hline Minggu 179 & 0.1597 \\
\hline Minggu 178 & 0.1810 \\
\hline Minggu 181 & 0.1720 \\
\hline Selanjutnya dari
\end{tabular}

Selanjutnya dari data yang telah diubah kedalam ascending kemudian dari data time series univariat diubah ke dalam multivariat dengan dilakukan percobaan pada yang terdiri dari 1 variabel independen sampai 12 variabel independen dengan masing-masing 1 variabel dependen. Data inilah yang akan digunakan pada proses pelatihan dalam menentukan arsitektur terbaik.

Tabel 3. Data multivariat satu periode

\begin{tabular}{|c|c|}
\hline $\mathrm{xt}-1$ & $\mathrm{xt}$ \\
\hline 0.1038 & 0.1024 \\
\hline 0.1024 & 0.1038 \\
\hline 0.1038 & 0.1024 \\
\hline 0.1274 & 0.1038 \\
\hline 0.1351 & 0.1274 \\
\hline 0.1256 & 0.1351 \\
\hline 0.1368 & 0.1256 \\
\hline 0.1578 & 0.1368 \\
\hline 0.1564 & 0.1578 \\
\hline 0.2126 & 0.1564 \\
\hline 0.1720 & 0.2126 \\
\hline 0.1825 & 0.1720 \\
\hline 0.1597 & 0.1825 \\
\hline 0.1810 & 0.1597 \\
\hline 0.1586 & 0.1810 \\
\hline 0.1783 & 0.1586 \\
\hline 0.1875 & 0.1783 \\
\hline 0.1504 & 0.1875 \\
\hline 0.1327 & 0.1504 \\
\hline
\end{tabular}

doi:10.30869, issn:2252-4002/2546-558X

PREDIKSI HASIL PRODUKSI IKAN TUNA MENGGUNAKAN ALGORITMA NEURAL NETWORK

BERBASIS FORWARD SELECTION
0.2180
0.1327

Selanjutnya dari data yang telah di lakukan tahap preprocessing dengan melakukan normalisasi data kemudian akan dilakukan proses dengan menggunkan algoritma Neural Network untuk menentukan model arsitektur terbaik. Berikut ini adalah hasil uji coba pencarian arsitektur terbaik dengan menggunakan metode Neural Network yang proses dengan menggunakan tollsrapidminer yang nantinya akan diukur berdasarkan perolehan nilai Root Mean Square Error (RMSE) dengan melakuakan penentuan parameter pada metode Neural Network yang nantinya akan menemukan model terbaik untuk melakukan prediksi yaitu dengan melakukan pencarian nilai terbaik pada setiap parameter yang ada. Adapun hasil uji coba penentuan parameter dapat di lihat pada tabel 4 .

Tabel 4. Penentuan Parameter Pada Neural Network

\begin{tabular}{|c|c|c|c|c|}
\hline $\begin{array}{c}\text { ARSITEKTUR } \\
\text { NEURAL } \\
\text { NETWORK }\end{array}$ & $\mathrm{TC}$ & LR & M & RMSE \\
\hline $1-1-1$ & 500 & 0.3 & 0.2 & $0.116+/-0.071$ \\
\hline $2-1-1$ & 500 & 0.3 & 0.2 & $0.118+/-0.054$ \\
\hline $2-2-1$ & 500 & 0.3 & 0.2 & $0.097+/-0.038$ \\
\hline $3-1-1$ & 500 & 0.3 & 0.2 & $0.110+/-0.044$ \\
\hline $3-2-1$ & 500 & 0.3 & 0.2 & $0.119+/-0.068$ \\
\hline $3-3-1$ & 500 & 0.3 & 0.2 & $0.128+/-0.083$ \\
\hline $4-1-1$ & 500 & 0.3 & 0.2 & $0.107+/-0.056$ \\
\hline $4-2-1$ & 500 & 0.3 & 0.2 & $0.120+/-0.054$ \\
\hline 4-3-1 & 500 & 0.3 & 0.2 & $0.098+/-0.036$ \\
\hline $4-4-1$ & 500 & 0.3 & 0.2 & $0.098+/-0.028$ \\
\hline $5-1-1$ & 500 & 0.3 & 0.2 & $0.112+/-0.052$ \\
\hline $5-2-1$ & 500 & 0.3 & 0.2 & $0.117+/-0.055$ \\
\hline $5-3-1$ & 500 & 0.3 & 0.2 & $0.116+/-0.037$ \\
\hline $5-4-1$ & 500 & 0.3 & 0.2 & $0.148+/-0.079$ \\
\hline $5-5-1$ & 500 & 0.3 & 0.2 & $0.101+/-0.032$ \\
\hline $6-1-1$ & 500 & 0.3 & 0.2 & $0.107+/-0.050$ \\
\hline $6-2-1$ & 500 & 0.3 & 0.2 & $0.130+/-0.069$ \\
\hline $6-3-1$ & 500 & 0.3 & 0.2 & $0.130+/-0.044$ \\
\hline $6-4-1$ & 500 & 0.3 & 0.2 & $0.116+/-0.034$ \\
\hline $6-5-1$ & 500 & 0.3 & 0.2 & $0.132+/-0.053$ \\
\hline $6-6-1$ & 500 & 0.3 & 0.2 & $0.137+/-0.072$ \\
\hline $7-1-1$ & 500 & 0.3 & 0.2 & $0.133+/-0.072$ \\
\hline $7-2-1$ & 500 & 0.3 & 0.2 & $0.107+/-0.053$ \\
\hline $7-3-1$ & 500 & 0.3 & 0.2 & $0.110+/-0.056$ \\
\hline $7-4-1$ & 500 & 0.3 & 0.2 & $0.125+/-0.048$ \\
\hline $7-5-1$ & 500 & 0.3 & 0.2 & $0.136+/-0.062$ \\
\hline
\end{tabular}




\begin{tabular}{|c|c|c|c|c|c|c|c|c|c|c|c|c|}
\hline & 7-6-1 & & 00 & 0.3 & 0.2 & $0.110+/$ & $0.048-2-1$ & 500 & 0 . & 0.2 & \multicolumn{2}{|c|}{$0.228+/-0.227$} \\
\hline $7-7-1$ & 500 & 0.3 & 0.2 & \multicolumn{2}{|c|}{$0.112+/-0.056$} & \multicolumn{3}{|c|}{$12-3-1$} & 500 & 0.3 & 0.2 & $0.172+/-0.081$ \\
\hline $8-1-1$ & 500 & 0.3 & 0.2 & \multicolumn{2}{|c|}{$0.124+/-0.055$} & & & & 500 & 0.3 & 0.2 & $0.140+/-0.054$ \\
\hline $8-2-1$ & 500 & 0.3 & 0.2 & \multicolumn{2}{|c|}{$0.126+/-0.066$} & & & & 500 & 0.3 & 0.2 & $0.149+/-0.063$ \\
\hline $8-3-1$ & 500 & 0.3 & 0.2 & \multicolumn{2}{|c|}{$0.180+/-0.160$} & & & & 500 & 0.3 & 0.2 & $0.166+/-0.056$ \\
\hline 8-4-1 & 500 & 0.3 & 0.2 & \multicolumn{2}{|c|}{$0.150+/-0.066$} & & & & 500 & 0.3 & 0.2 & $0.157+/-0.061$ \\
\hline $8-5-1$ & 500 & 0.3 & 0.2 & \multicolumn{2}{|c|}{$0.142+/-0.058$} & & & & 500 & 0.3 & 0.2 & $0.153+/-0.064$ \\
\hline $8-6-1$ & 500 & 0.3 & 0.2 & \multicolumn{2}{|c|}{$0.116+/-0.052$} & & & & 500 & 0.3 & 0.2 & $0.169+/-0.087$ \\
\hline $8-7-1$ & 500 & 0.3 & 0.2 & \multicolumn{2}{|c|}{$0.121+/-0.052$} & & & & 500 & 0.3 & 0.2 & $0.162+/-0.069$ \\
\hline $8-8-1$ & 500 & 0.3 & 0.2 & \multicolumn{2}{|c|}{$0.162+/-0.090$} & & & & 500 & 0.3 & 0.2 & $0.141+/-0.060$ \\
\hline $9-1-1$ & 500 & 0.3 & 0.2 & \multicolumn{2}{|c|}{$0.132+/-0.046$} & & & & 500 & 0.3 & 0.2 & $0.142+/-0.061$ \\
\hline
\end{tabular}

Berdasarkan hasil pengujian yang terlihat pada tabel 3 bahwa nilai Root Mean Square Error (RMSE) terkecil berada pada jumlah input layerxt-9, hidden layer 1 , neuron size 5 dengan nilai Root Mean Square Error (RMSE) adalah $0.096+/-0.033$.

Berikut ini adalah hasil uji coba pencarian arsitektur terbaik dengan menggunakan metode Neural Network berbasis forward selection yang nantinya akan diukur berdasarkan perolehan nilai Root Mean Square Error (RMSE) dengan melakuakan penentuan parameter pada metode Neural Network yang nantinya akan menemukan model terbaik untuk melakukan prediksi yaitu dengan melakukan pencarian nilai terbaik pada setiap parameter yang ada. Adapun hasil uji coba penentuan parameter dapat di lihat pada tabel 5 .

Tabel 5. Penentuan Parameter Pada Neural Network berbasis Forward Selection

\begin{tabular}{|c|c|c|c|c|}
\hline $\begin{array}{c}\text { ARSITEKTUR } \\
\text { NEURAL } \\
\text { NETWORK }\end{array}$ & TC & LR & M & RMSE \\
\hline $1-1-1$ & 500 & 0.3 & 0.2 & $0.116+/-0.071$ \\
\hline $2-1-1$ & 500 & 0.3 & 0.2 & $0.099+/-0.042$ \\
\hline $2-2-1$ & 500 & 0.3 & 0.2 & $0.099+/-0.031$ \\
\hline $3-1-1$ & 500 & 0.3 & 0.2 & $0.090+/-0.032$ \\
\hline $3-2-1$ & 500 & 0.3 & 0.2 & $0.090+/-0.037$ \\
\hline $3-3-1$ & 500 & 0.3 & 0.2 & $0.097+/-0.035$ \\
\hline $4-1-1$ & 500 & 0.3 & 0.2 & $0.096+/-0.044$ \\
\hline $4-2-1$ & 500 & 0.3 & 0.2 & $0.095+/-0.037$ \\
\hline $4-3-1$ & 500 & 0.3 & 0.2 & $0.106+/-0.032$ \\
\hline $4-4-1$ & 500 & 0.3 & 0.2 & $0.102+/-0.037$ \\
\hline $5-1-1$ & 500 & 0.3 & 0.2 & $0.098+/-0.047$ \\
\hline $5-2-1$ & 500 & 0.3 & 0.2 & $0.094+/-0.047$ \\
\hline $5-3-1$ & 500 & 0.3 & 0.2 & $0.103+/-0.04$ \\
\hline
\end{tabular}




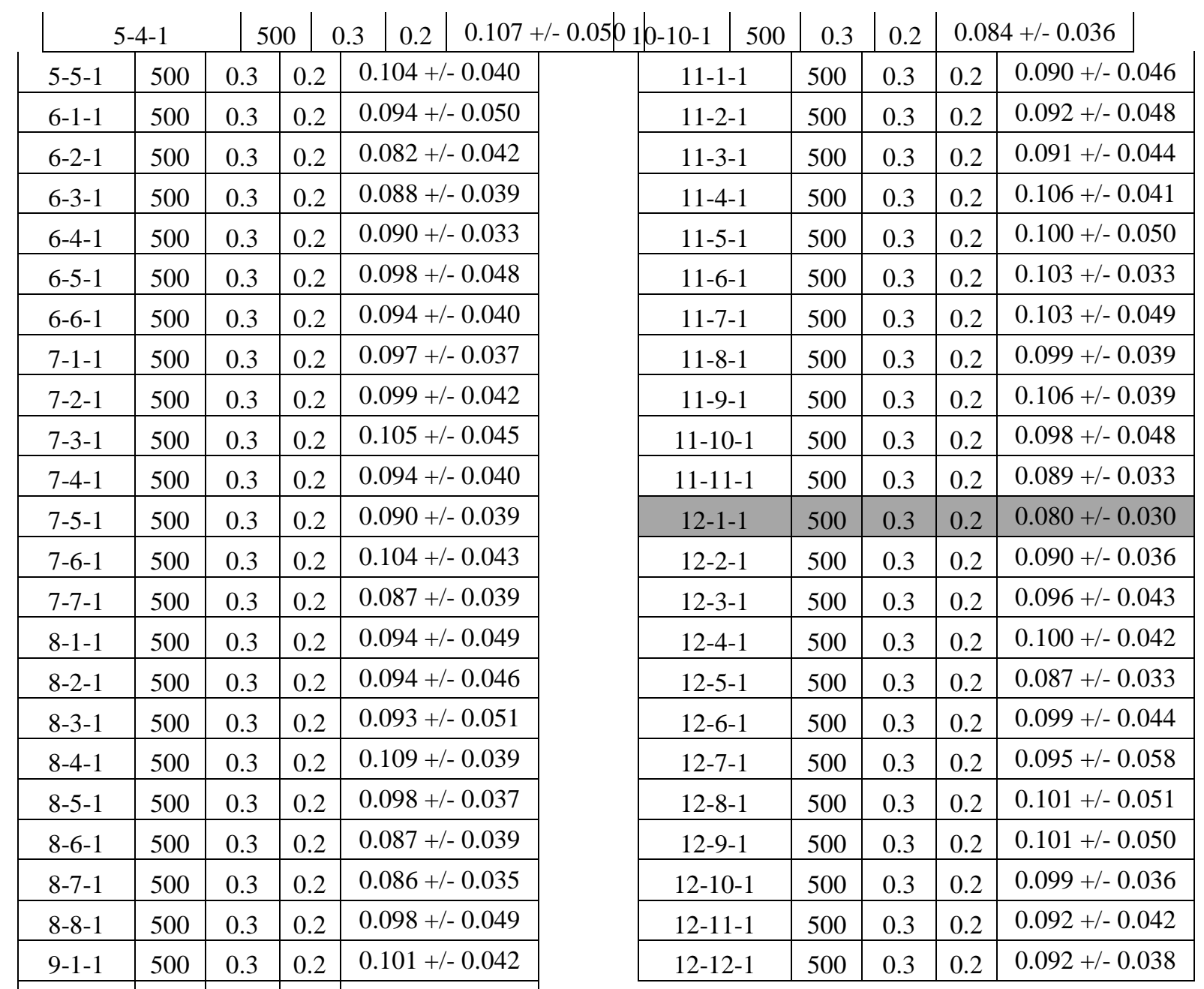

Berdasarkan hasil pengujian yang terlihat pada tabel 5.16 bahwa nilai Root Mean Square Error (RMSE) terkecil berada pada jumlah input layerxt-12, hidden layer 1, neuron size 1 dengan nilai Root Mean Square Error (RMSE) adalah $0.080+/-0.030$.

Berdasarkan hasil ekperimen yang dilakukan pada tahapan-tahapan sebelumnya, diperoleh hasil nilai Root Mean Square Error terbaik dengan menggunakan metode Neural Network yaitu sebesar 0,096 dan hasil pengujian metode Neural Network berbasis Forward Selection mampu mengahasilkan nilai Root Mean Square Error yang lebih kecil yaitu sebesar 0,080. Dengan demikian metode Neural Network berbasisForward Selection terbukti mampu 
menghasilkan nilai yang lebih baik jika dibandingkan dengan menggunakan metode Neural Network yang dapat dilihat pada tabel 6.

Tabel 6. Perbandingan Hasil RMSE untuk Metode Neural Network dan Neural NetworkBerbasis Forward Selection

\begin{tabular}{|l|l|}
\hline Metode & $\begin{array}{l}\text { Hasil } \\
\text { RMSE }\end{array}$ \\
\hline Neural Network & $\mathbf{0 , 0 9 6}$ \\
\hline $\begin{array}{l}\text { Neural NetworkBerbasis } \\
\text { Forward Selection }\end{array}$ & $\mathbf{0 , 0 8 0}$ \\
\hline
\end{tabular}

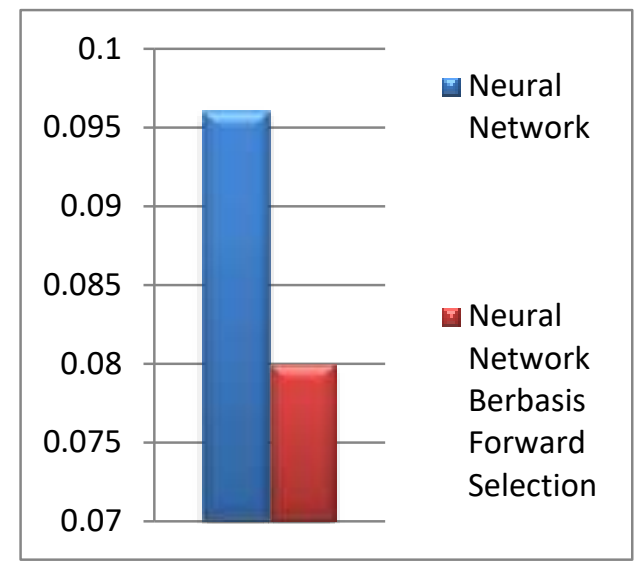

Gambar 2. Perbandingan Hasil RMSE untuk Metode

Neural Network dan Neural NetworkBerbasis Forward Selection

Berdasarkan hasil perhitungan selisih dari metode Neural Network dan metode Neural Network Bebasis Forward Selection didapatkan hasil selisih yaitu sebesar 0,016. Dengan demikian bahwa hasil ekperimen yang didapatkan pada metode Neural Network Bebasis Forward Selection dengan model terbaik yang didapat yaitu parameter pada Neural Network dengan jumlah input layer 12, dengan hidden layer 1 jumlah neuron size 1 , training cycle 500, learning rate 0.3 dan momentum 0.2. Model ini akan dilakukan pengujian dengan dataset training tahun 2014 sampai 2016 untuk melakukan prediksi pada tahun 2017 yaitu pada minggu ke 1 sampai dengan 48 .
Tabel 7. Data testing 2017 hasil prediksi dalam denormalisasi

\begin{tabular}{|c|c|c|r|}
\hline $\begin{array}{c}\text { Minggu } \\
\text { Ke }\end{array}$ & $\begin{array}{c}\text { Data } \\
\text { Aktual } \\
\mathbf{2 0 1 7}\end{array}$ & $\begin{array}{c}\text { Hasil } \\
\text { Peramalan }\end{array}$ & \multicolumn{1}{l|}{ Error } \\
\hline 1 & 19147 & 8942 & -10205 \\
\hline 2 & 16433 & 14784 & -1649 \\
\hline 3 & 18144 & 14214 & -3930 \\
\hline 4 & 20881 & 15836 & -5045 \\
\hline 5 & 20564 & 18360 & -2204 \\
\hline 6 & 19426 & 19142 & -284 \\
\hline 7 & 18619 & 17523 & -1096 \\
\hline 8 & 17345 & 16153 & -1193 \\
\hline 9 & 20700 & 14660 & -6040 \\
\hline 10 & 12378 & 18559 & 6182 \\
\hline 11 & 8797 & 11559 & 2762 \\
\hline 12 & 11330 & 6562 & -4768 \\
\hline 13 & 13418 & 8656 & -4761 \\
\hline 14 & 8262 & 11016 & 2755 \\
\hline 15 & 16403 & 6773 & -9630 \\
\hline 16 & 14413 & 12445 & -1968 \\
\hline 17 & 18755 & 12566 & -6189 \\
\hline 18 & 22434 & 16207 & -6227 \\
\hline 19 & 17210 & 19608 & 2399 \\
\hline 20 & 27937 & 14821 & -13116 \\
\hline 21 & 11782 & 23782 & 12000 \\
\hline 22 & 14865 & 12346 & -2519 \\
\hline 23 & 7327 & 10340 & 3013 \\
\hline 24 & 11435 & 6283 & -5152 \\
\hline 25 & 8231 & 7949 & -283 \\
\hline 26 & 7937 & 6639 & -1299 \\
\hline 27 & 8360 & 6139 & -2221 \\
\hline 28 & 9128 & 5787 & -3342 \\
\hline 29 & 2698 & 7505 & 4807 \\
\hline 30 & 4032 & 1747 & -2286 \\
\hline 31 & 6829 & 1510 & -5319 \\
\hline 32 & 6136 & 3500 & -2636 \\
\hline 33 & 4651 & 3728 & -922 \\
\hline 34 & 6339 & 2539 & -3800 \\
\hline 35 & 4733 & 3236 & -1498 \\
\hline 36 & 6452 & 2670 & -3782 \\
\hline & 5661 & 3551 & -2110 \\
\hline
\end{tabular}




\begin{tabular}{|r|r|r|r|}
38 & 8721 & 2757 & -5964 \\
\hline 39 & 4485 & 4719 & 234 \\
\hline 40 & 4590 & 2898 & -1692 \\
\hline 41 & 3007 & 2126 & -881 \\
\hline 42 & 2163 & 1142 & -1021 \\
\hline 43 & 2879 & 626 & -2253 \\
\hline 44 & 2299 & 859 & -1440 \\
\hline 45 & 519 & 747 & 227 \\
\hline 46 & 414 & -254 & -668 \\
\hline 47 & 519 & -334 & -854 \\
\hline 48 & 414 & -518 & -932 \\
\hline
\end{tabular}

HASIL PERBANDINGAN ANTARA DATA AKTUAL DAN HASIL PERAMALAN

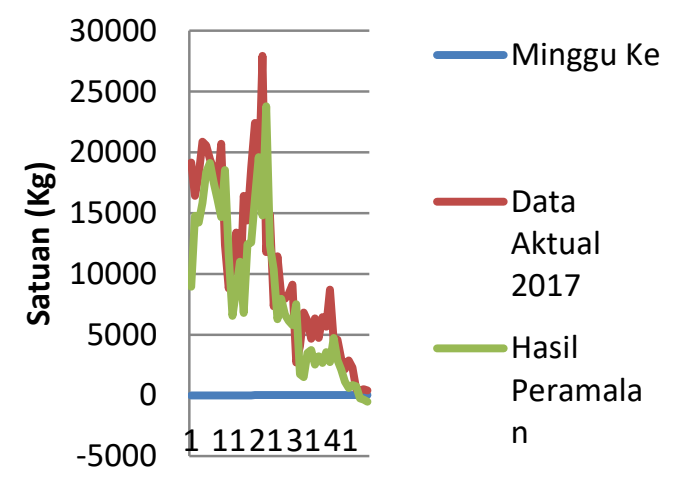

Gambar 3. Hasil Perbandingan Antara Data Aktual dan Hasil Peramalan

Pada tabel 7 dan gambar 3 di atas menunjukkan bahwa hasil prediksi yang dilakukan terhadap data tahun 2017 pada minggu 1 sampai dengan 48 sudah menunjukkan perbandingan nilai error yang kecil dari jumlah data yang diperoleh. Dengan hasil nilai Root Mean Square Error sebesar 0.0604073. Hal ini dapat dijadikan sebagai acuan terhadap tingkat error yang akan dilakukan prediksi pada tahun akan datang.

Dengan menerapakan hasil model terbaik yang telah didapatkan oleh metode Neural Network Berbasis Forward Selection maka dapat digunakan untuk melakukan prediksi pada tahun 2018 pada minggu 1 sampai dengan 48 . Dengan mengunakan dataset dari tahun 2014 sampai dengan 2017 yang di jadikan sebagai training pada tahun 2018 merupakan output atau hasil prediksi. Seperti yang terlihat pada tabel 8 dibawah ini.
Tabel 8. Prediksi Hasil Produksi Ikan Tuna Tahun 2018

\begin{tabular}{|c|c|c|}
\hline \multicolumn{3}{|c|}{ Prediksi 2018} \\
\hline Minggu Ke & Normalisasi & Denormalisasi \\
\hline 1 & 0.1178 & 1574 \\
\hline 2 & 0.1174 & 1542 \\
\hline 3 & 0.1196 & 1714 \\
\hline 4 & 0.1386 & 3144 \\
\hline 5 & 0.1489 & 3916 \\
\hline 6 & 0.1381 & 3104 \\
\hline 7 & 0.1484 & 3879 \\
\hline 8 & 0.1658 & 5190 \\
\hline 9 & 0.1659 & 5204 \\
\hline 10 & 0.2199 & 9269 \\
\hline 11 & 0.1805 & 6304 \\
\hline 12 & 0.1915 & 7129 \\
\hline 13 & 0.1669 & 5275 \\
\hline 14 & 0.1860 & 6713 \\
\hline 15 & 0.1706 & 5555 \\
\hline 16 & 0.1888 & 6930 \\
\hline 17 & 0.1976 & 7587 \\
\hline 18 & 0.1621 & 4918 \\
\hline 19 & 0.1491 & 3936 \\
\hline 20 & 0.2283 & 9904 \\
\hline 21 & 0.2255 & 9691 \\
\hline 22 & 0.2164 & 9011 \\
\hline 23 & 0.2374 & 10588 \\
\hline 24 & 0.2714 & 13154 \\
\hline 25 & 0.2190 & 9206 \\
\hline 26 & 0.3214 & 16925 \\
\hline 27 & 0.2734 & 13301 \\
\hline 28 & 0.4644 & 27706 \\
\hline 29 & 0.3426 & 18523 \\
\hline 30 & 0.4111 & 23687 \\
\hline 31 & 0.3658 & 20270 \\
\hline 32 & 0.3047 & 15664 \\
\hline 33 & 0.3359 & 18018 \\
\hline 34 & 0.2302 & 10047 \\
\hline
\end{tabular}

doi:10.30869, issn:2252-4002/2546-558X 


\begin{tabular}{|l|l|l|}
\hline 35 & 0.2997 & 15288 \\
\hline 36 & 0.2714 & 13154 \\
\hline 37 & 0.2363 & 10511 \\
\hline 38 & 0.2884 & 14435 \\
\hline 39 & 0.3980 & 22698 \\
\hline 40 & 0.3542 & 19397 \\
\hline 41 & 0.3689 & 20505 \\
\hline 42 & 0.3814 & 21448 \\
\hline 43 & 0.3879 & 21939 \\
\hline 44 & 0.3944 & 22425 \\
\hline 45 & 0.3613 & 19934 \\
\hline 46 & 0.3432 & 18567 \\
\hline 47 & 0.3721 & 20746 \\
\hline 48 & 0.2672 & 12835 \\
\hline
\end{tabular}

dataset hasil produksi ikan tuna provinsi gorontalo yang dimulai dari tahun 2014 sampai dengan 2017 dengan menerapkan metode Neural Network Berbasis Forward Selection didapatkan arsitektur terbaik yang dapat digunakan dalam memprediksi hasil produksi ikan tuna provinsi gorontalo kedepannya. Dengan mendapatkan model terbaik pada metod Neural Network Berbasis Forward Selection yaitu dengan jumlah input layer 12, hidden layer 1 jumlah neuron size 1, training cycle 500, learning rate 0.3 dan momentum 0.2 yang menghasilkan nilai Root Mean Square Erroryaitu 0,080. Hal ini membuktikan bahwa dengan menerapkan pola yang didapatkan oleh metode Neural Network Berbasis Forward Selection dalam melakukan prediksi mampu mengurangi nilai Root Mean Square Error jika dibandingkan dengan hanya menggunakan metode Neural Network saja. Saran

Berdasarkan hasil eksperimen yang dilakukan terhadap metode Neural Network Berbasis Forward Selection yang mampu mengurangi nilai error, adapun untuk penelitian selanjutnya ada beberapa saran diantanya seperti:

1. Menerapkan metode Neural Network Berbasis Forward Selectiondilakukan percobaan lagi dengan menggunakan dataset time series yang berbeda.

2. Melakukan percobaan dengan menggunakan metode Forward Selection dengan menggunakan algoritma lain untuk prediksi yang akan dijadikan sebagai pembanding kinerja algoritma.

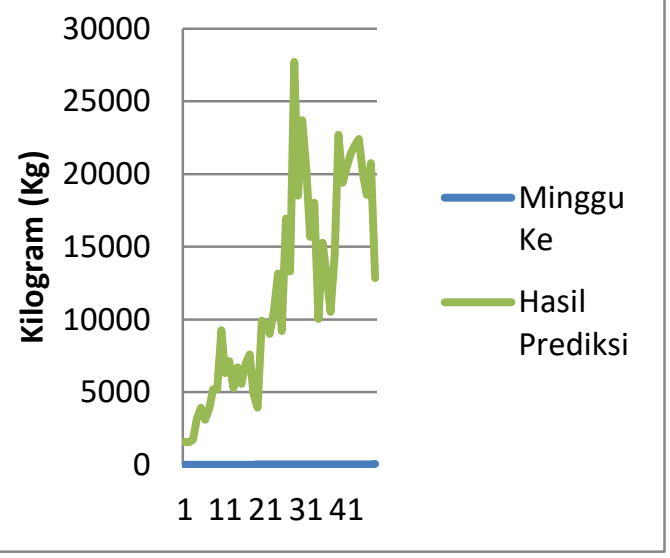

Gambar 4. Hasil Prediksi Produksi Ikan Tuna Tahun 2018

Berdasarkan hasil dari tabel 8 dan gambar 4 merupakan hasil yang dilakukan untuk memprediksi pada tahun 2018 pada minggu 1 sampai dengan minggu ke 48 dengan menerapkan metode Neural Network Berbasisis Forward Selection berdasarkan hasil dari parameter-parameter yang telah dilakukan ujicoba sebelumnya.

\section{KESIMPULAN}

Berdasarkan hasil uji coba dan analisa yang telah dilakukan dengan menggunakan

\section{DAFTAR PUSTAKA}

Dinas Perikanan \& Kelautan Provinsi Gorontalo Rencana Strategis (Renstra) Pembangunan ., 2012 - 2017. Perikanan \& Kelautan Provinsi Gorontalo

Dinas Perikanan dan Kelautan Provinsi Gorontalo., 20152019. Profil Sektor Perikanan dan Kelautan Gorontalo dan UPTD.

C. Yao Lo, C. I Hou, and Y. Yun Pai., 2011. An Intelligent Demand Forecasting Model with Back Propagation Neural Network for Fish Product. Journal of Applied Sciences, Engineering and Technology. Vol. III, no. 5, pp. 447-455.

Y.H. Zweiri, J.F. Whidborne and L.D,. 2003 Seneviratne $A$ three-term backpropagation algorithm. Neurocomputing 50-305-318.

Prasetyo Eko., 2014. Data Mining - Mengolah Data Menjadi Informasi menggunakan Matlab, Andi offset, Yogyakarta

Purwanto, C. Eswara, and R. Logeswara,. 2011. Improved Adaptive Neuro-fuzzy Inference System for HIV/AIDSTime series Prediction. In: Informatics Engineering andInformation Science, 253, SpringerVerlag BerlinHeidelberg, pp. 1-1 